\title{
The phylogenetic position of the enigmatic Balkan Aulopyge huegelii (Teleostei: Cyprinidae) from the perspective of host- specific Dactylogyrus parasites (Monogenea), with a description of Dactylogyrus omenti n. sp.
}

Michal Benovics ${ }^{*}$ Maria Lujza Kičinjaová and Andrea Šimková

\begin{abstract}
Background: The host specificity of fish parasites is considered a useful parasite characteristic with respect to understanding the biogeography of their fish hosts. Dactylogyrus Diesing, 1850 (Monogenea) includes common parasites of cyprinids exhibiting different degrees of host specificity, i.e. from strict specialism to generalism. The phylogenetic relationships and historical dispersions of several cyprinid lineages, including Aulopyge huegelii Heckel, 1843, are still unclear. Therefore, the aims of our study were to investigate (i) the Dactylogyrus spp. parasites of $A$. huegelii, and (ii) the phylogenetic relationships of Dactylogyrus spp. parasitizing A. huegelii as a possible tool for understanding the phylogenetic position of this fish species within the Cyprininae lineage.

Results: Two species of Dactylogyrus, D. vastator Nybelin, 1924 and D. omenti n. sp., were collected from 14 specimens of A. huegelii from the Šujica River (Bosnia and Herzegovina). While D. vastator is a typical species parasitizing Carassius spp. and Cyprinus carpio L, D. omenti n. sp. is, according to phylogenetic reconstruction, closely related to Dactylogyrus species infecting European species of Barbus and Luciobarbus. The genetic distance revealed that the sequence for $D$. vastator from A. huegelii is identical with that for D. vastator from Barbus plebejus Bonaparte, 1839 (Italy) and Carassius gibelio (Bloch, 1782) (Croatia). Dactylogyrus omenti n. sp. was described as a species new to science.

Conclusions: Our findings support the phylogenetic position of $A$. huegelii within the Cyprininae lineage and suggest that A. huegelii is phylogenetically closely related to Barbus and Luciobarbus species. The morphological similarity between D. omenti n. sp. and Dactylogyrus species of Middle Eastern Barbus suggests historical contact between cyprinid species recently living in allopatry and the possible diversification of $A$. huegelii from a common ancestor in this area. On other hand, the genetic similarity between D. vastator ex A. huegelii and D. vastator ex C. gibelio collected in Balkan Peninsula suggests that $A$. huegelii was secondarily parasitized by D. vastator, originating from C. gibelio after introduction of this fish species from Asia to Europe.
\end{abstract}

Keywords: Host specificity, Coevolution, Phylogeography, Aulopyge, Cyprininae, Dactylogyrus

* Correspondence: michal.benovics@gmail.com

Department of Botany and Zoology, Faculty of Science, Masaryk University, Kotlárská 2, 61137 Brno, Czech Republic 


\section{Background}

Parasites and their hosts are usually closely associated due to their coevolution, realized by reciprocal genetic adaptations between these interacting species. In evolutionary time, this leads to a selection for improvements in host-parasite recognition mechanisms [1]. The high degree of host specificity among parasites (generally, a parasite species is restricted to a single host species), reflecting parasite specialization, may arise from such coevolutionary interactions [2-4] In the case of high host specificity, the phylogeny of host-specific parasites may even follow the phylogeny and historical biogeography of their hosts as a result of co-speciation $[5,6]$. However, parasite diversification can also be driven by host specialization following host switching resulting from strong ecological association, as was shown for monogeneans of marine fish [7]. The host specificity of freshwater fish parasites appears to be a useful characteristic in terms of understanding the biogeography of freshwater fishes (e.g. [8-11]). Basic host specificity is commonly expressed by the number of host species (also termed host range). However, other aspects, like the ecological performance of the parasite, the phylogenetic affinities of hosts, and the biogeographical distribution of the parasite, are important when expressing host specificity [12].

Gill ectoparasites of the genus Dactylogyrus Diesing, 1850 generally exhibit a high degree of host specificity and a high species diversity arising from the multitude of cyprinid fish species, which are common hosts of these parasite species [13]. Šimková et al. [14] defined several levels of host specificity for Dactylogyrus using an index of host specificity, expressed as the inverted value of the index of non-specificity proposed by Desdevises et al. [7]. Five Dactylogyrus groups were defined ranging from strict specialists, which occur on a single host species, to true generalists, which parasitize different, phylogenetically unrelated cyprinid host species. These host-specific parasites have a direct life-cycle, in which the larval stage (oncomiracidium) actively searches for suitable host species, using chemical cues for host recognition [15]. Therefore, among monogeneans, a high degree of adaptation to their host resource is required [16-19]. Several studies documented microhabitat restriction (i.e. preferred niche measured by specific gill positions) in Dactylogyrus species [20-24]. Since different parts of gills offer different types of substrate, niche preference is associated with a specific type and shape of attachment organ (haptor) in parasites assigned to Dactylogyrus [9, 21, 23]. Šimková et al. [23] also revealed that there is morphological adaptation of the haptor in species that specifically parasitize phylogenetically related hosts, such as Dactylogyrus species parasitizing Cyprinus carpio L. and Carassius auratus L. of the subfamily Cyprininae. The phylogeny of highly hostspecific Dactylogyrus species reflects the biogeography and evolutionary history of their cyprinid hosts [25]. Besides some accidental infections of unsuitable hosts, the sharing of Dactylogyrus species among evolutionary divergent cyprinid species living in sympatry is rare [23].

The cyprinid fauna of the Balkan Peninsula is extremely rich in endemic species [26]. According to Oikonomou et al. [27], the Balkan freshwater fish fauna represents 59\% of all known cyprinid species. The ancient Dessaretes lake system played an important role in cyprinid speciation, which originated during the Pleistocene and is considered as a hotspot of endemic freshwater biodiversity [28-32]. Presently, all the great lakes in the Balkan Peninsula, the Ohrid, Prespa, Mikri Prespa and Maliq lakes (the latter one was drained after World War II), are parts of this system. Albrecht \& Wilke [30] also theorized that during the Miocene and Pliocene eras the whole Dessaretes basin was filled with water and that all lakes were connected. After the closing of the Korca Depression and connections between the Dessaretes and the Paratethys, the water level decreased and fragmentation of the populations triggered allopatric speciation, which led to rich freshwater fish diversity. Zardoya et al. [33] investigated the geographical origin of Balkan endemic cyprinids. They suggested that cyprinid fauna colonized the Balkan Peninsula during two different time periods. The first wave occurred during the Miocene and the second during the Plio-Pleistocene via river captures. The phylogenetic relationships among Balkan cyprinid taxa and their biogeographical histories have been actively studied over the last 25 years (e.g. [34-40]). Studying host-specific parasites, such as Dactylogyrus, may represent an additional tool for investigation and may shed more light on both the historical contacts between cyprinid hosts and their phylogeography.

The Dalmatian barbelgudgeon (Aulopyge huegelii Heckel, $1843)$, the only representative of the monotypic genus Aulopyge, is one of the many endangered cyprinid species of the Balkan Peninsula. Its distribution is limited to the Dinaric karst rivers and lakes of Croatia and Bosnia and Herzegovina [41-43]. Although previously quite abundant, in recent years $A$. huegelii populations have been declining [44]. Tsigenopoulos \& Berrebi [43] considered the ancestor of $A$. huegelii as the first migration wave of cyprinids to the Mediterranean region, which found refuge in Dalmatia. According to the molecular clock, they estimated that European Barbus and A. huegelii diverged during the middle Miocene, which concurs with the first wave colonizing Balkan Peninsula [33]. On the basis of mitochondrial cytochrome $b$ sequence data, Tsingenopoulos et al. [45] suggested that $A$. huegelii is the sister clade to the clade including Barbus + Luciobarbus lineages. However, Yang et al. [46] showed that Aulopyge is the sister taxon to the the European Barbus lineage, well separated from the Luciobarbus lineage, and, according to Wang et al. [47], the 
European Barbus (sensu stricto) lineage and A. huegelii share a common ancestor (originating in the QinghaiTibetan Plateau region about 19.4-7.8 Mya) with the species of the Asian genera Schizothorax and Cyprinion.

Until now, only a very few endemic cyprinid species from the Balkan Peninsula have been investigated for parasites [48-54]. As previously shown by Šimková et al. [25], phylogenetic relationships between Dactylogyrus lineages can reflect cyprinid phylogeny. Thus, we hypothesized that the phylogenetic relationships between host-specific Dactylogyrus species of A. huegelii and those parasitizing other closely related cyprinid species will support the phylogenetic position of this monotypic cyprinid genus. Therefore, the aims of our study were (i) to investigate the Dactylogyrus fauna of endemic A. huegelii, and (ii) to investigate the phylogenetic relationships between Dactylogyrus species parasitizing A. huegelii and those parasitizing species of the Cyprininae distributed in Europe, i.e. Barbus spp., Carassius spp. and C. carpio (the last two originating from Asia and widely distributed throughout the whole of Europe). As a result, we described a new species of Dactylogyrus collected from endemic A. huegelii.

\section{Methods}

\section{Sampling and species identification}

A total of 14 specimens of Aulopyge huegelii from the Šujica River, Bosnia and Herzegovina, were sampled in July 2015. Fish were dissected using standard methods [55]. Dactylogyrus specimens were collected from host gills, fins, head surfaces, and oral and nasal cavities, mounted on slides and covered with a mixture of glycerine and ammonium picrate (GAP [56]) for further identification. The identification of monogeneans was performed using Gussev [57] on the basis of the size and shape of the hard parts of the attachment organ, the haptor, and the reproductive organs which represent species-specific morphological characters. Identification to species level was performed using an Olympus BX51 microscope equipped with phase contrast optics. Several Dactylogyrus specimens were bisected; one half of the body (usually the half with the reproductive organs) was mounted on a slide for species identification, the other was individually preserved in $96 \%$ ethanol for DNA extraction. Basic epidemiological data, i.e. prevalence, mean abundance, minimum and maximum intensity of infection, were calculated for each species according to Bush et al. [58]. Prevalence, as the percentage of fish infected by a given parasite species, and mean abundance, as the mean number of parasite specimens per individual host taking into account both infected and uninfected hosts, were calculated.

\section{Morphometric data}

Morphometric measurements of Dactylogyrus spp. specimens (modified according to Gussev [57]) were taken using Digital Image Analysis (Stream Motion). All measurements of morphometric characters are in micrometres and are presented as the range followed by the mean and the number of measured specimens $(n)$ in parentheses. The numbering of marginal hook pairs for Dactylogyrus follows the recommendations by Mizzele [59]. After measuring morphometric characters, the specimens were removed from GAP and remounted in Canada balsam, according to Ergens [60], and deposited as type-specimens in the Helminthological Collection of the Institute of Parasitology, Biology Centre of the Academy of Sciences of the Czech Republic, in České Budějovice (IPCAS).

\section{DNA extraction, amplification and sequencing}

Parasites were removed from storage ethanol and dried by means of a vacuum centrifuge. DNA extraction was performed using a standard protocol (DNeasy Blood \& Tissue Kit, Qiagen, Hilden, Germany). Partial 18S rDNA and entire ITS1 regions were amplified using primers S1 (5'-ATT CCG ATA ACG AAC GAG ACT-3') and IR8 (5'-GCT AGC TGC GTT CTT CAT CGA-3') [61], which anneal to the $18 \mathrm{~S}$ and $5.8 \mathrm{~S}$ rDNA regions, respectively. Each amplification reaction for partial the $18 \mathrm{~S}$ rDNA and ITS1 regions was performed in a final volume of $15 \mu \mathrm{l}$, containing $0.3 \mu \mathrm{l}$ of Taq polymerase, $1.5 \mu \mathrm{l}$ buffer, $0.9 \mu \mathrm{l} \mathrm{MgCl}$, $0.3 \mu \mathrm{l}$ of dNTPs, $1.5 \mu \mathrm{l}$ of each primer and $2.5 \mu \mathrm{l}$ of pure DNA $(20 \mathrm{ng} / \mu \mathrm{l})$. PCR was carried out using the following steps: 2 min at $94{ }^{\circ} \mathrm{C}$, followed by 40 cycles of $1 \mathrm{~min}$ at $94^{\circ}$ $\mathrm{C}, 1 \mathrm{~min}$ at $53{ }^{\circ} \mathrm{C}$ and $90 \mathrm{~s}$ at $72{ }^{\circ} \mathrm{C}$, and $10 \mathrm{~min}$ of final elongation at $72{ }^{\circ} \mathrm{C}$. Partial $28 \mathrm{~S}$ rDNA was amplified using the forward primer $\mathrm{C} 1$ (5'-ACC CGC TGA ATT TAA GCA-3') and the reverse primer D2 (5'-TGG TCC GTG TTT CAA GAC-3') [62]. PCR followed the protocol included in Šimková et al. [14]. PCR products were checked on $1.5 \%$ agarose gels, purified by using an ExoSAP-IT kit (Ecoli, Bratislava, Slovakia), following the manufacturer's protocol, and sequenced directly using the PCR primers and BigDye Terminator Cycle sequencing kit (Applied Biosystems, Pardubice, Czech Republic). Sequencing was carried out using an ABI 3130 Genetic Analyzer (Applied Biosystems). The newly generated sequences were deposited in the GenBank database and molecular vouchers (hologenophores, paragenophores [63]) were deposited in the Helminthological Collection of the Institute of Parasitology, Biology Centre of the Academy of Sciences of the Czech Republic, in České Budějovice (IPCAS).

\section{Phylogenetic analyses}

DNA sequences were aligned using fast Fourier transform in MAFFT [64]. To match the lengths of the newly obtained sequences to the sequences obtained from GenBank, they were optimized manually. A test of homogeneity to examine the congruence of two datasets (partial 18S with 
the ITS1 region vs 28S rDNA) was performed in PAUP* 4 b10 [65]. Since the difference was not statistically significant $(P=0.737)$, the concatenated data were used for further phylogenetic analyses. The sequences of Dactylogyrus extensus Mueller \& Van Cleave, 1932 parasitizing C. carpio were acquired from GenBank (accession numbers KM277459 and AY553629 for partial 18S rDNA with the ITS1 region and partial 28S rDNA sequences, respectively). The sequences of partial 18S rDNA with the ITS1 region and partial 28S rDNA for Dactylogyrus vastator Nybelin, 1924 and Dactylogyrus anchoratus (Dujardin, 1845) parasitizing Carassius gibelio (Bloch, 1782), and Dactylogyrus species parasitizing Barbus barbus L., B. balcanicus Kotlík, Tsigenopoulos, Ráb \& Berrebi, 2002, B. prespensis Karaman, 1924, Luciobarbus graecus (Steindachner, 1895) and L. albanicus (Steindachner, 1870) (including Balkan endemic and non-endemic Dactylogyrus species) were included in phylogenetic analyses due to the proposed evolutionary proximity of the host species. The final tree was rooted using Dactylogyrus species of C. gibelio and C. carpio as the outgroup taxa, following Šimková et al. [23].

To analyze the genetic distances between the specimens of $D$. vastator from different host species, sequences of partial $18 \mathrm{~S}$ rDNA and complete ITS1 available for $D$. vastator were obtained from GenBank. The uncorrected p-distances between $D$. vastator collected from 5 different host species from 7 localities were calculated using MEGA6 [66].

Gaps and ambiguously aligned regions were removed from the alignment using GBlocks v. 0.91 [67]. The most appropriate DNA evolution model was determined using the Akaike information criterion (AIC) in JModelTest 2.1.10 [68, 69]. Phylogenetic trees were inferred by Bayesian inference (BI) and Maximum Likelihood (ML) analyses using MrBayes 3.2 [70] and PhyML 3.0 [71], respectively. The search for the best ML tree was performed using NNI (nearest neighbour interchange) and SPR (subtree pruning and regrafting) branch swapping algorithms with six substitution categories. The clade support for ML was assessed by 1000 bootstrap pseudoreplicates. Bayesian inference trees were constructed using the $\mathrm{MC}^{3}$ algorithm with two parallel runs containing one cold and three hot chains. The analysis ran for $10^{7}$ generations and tree topologies were sampled every 100 generations. The first $25 \%$ of all saved trees were discarded as relative 'burn-in' periods according to standard deviation split frequencies $(<0.01)$. Posterior probabilities were calculated as the frequency of samples recovering any particular clade.

\section{Results}

Parasites of $A$. huegelii

All 14 dissected fish specimens were infected with monogenean parasites. Dactylogyrus spp. reached 93\% prevalence in A. huegelii and represented two species. The first was Dactylogyrus vastator, a common parasite of Carassius spp. and C. carpio, and which also accidentaly infects some other fish species ([13], M. Benovics, unpublished data). Morphological identification confirmed that specimens of $D$. vastator from $A$. huegelii possess the same morphology of the hard parts of the haptor and reproductive organs (i.e. the shape was identical and the size of these parts was within the range of sizes included in original description of D. vastator). The second species is here described as Dactylogyrus omenti n. sp., which was not found on other endemic Barbus species, or any other cyprinids collected in the Balkan Peninsula, and is most likely specific to A. huegelii. Both Dactylogyrus species differed in their epidemiological characteristics (Table 1). The prevalence of $D$. omenti $\mathrm{n}$. sp. was significantly higher than that of $D$. vastator (Fisher's exact test, $P=0.006$, $d f=1)$. The abundance of $D$. omenti $\mathrm{n}$. sp. was higher than that of D. vastator (Mann-Whitney test, $U_{(14)}=15.00$, $Z=3.79, P<0.001)$.

\section{Phylogenetic position of Dactylogyrus spp. parasitizing A. huegelii}

A final concatenated sequence alignment was constructed using 1625 unambiguously aligned nucleotide positions. GTR + I + G was selected as the optimal evolution model. $\mathrm{ML}$ and $\mathrm{BI}$ analyses provided phylogenetic trees with similar topologies. The BI tree is presented in Fig. 1, where bootstrap values resulting from ML analysis and posterior probabilities resulting from $\mathrm{BI}$ analysis are included. Collection localities and GenBank accession numbers of all newly generated sequences used in the phylogenetic reconstructions are provided in Table 2.

The resulting tree for Dactylogyrus spp. supports the close phylogenetic relationship of $A$. huegelii to endemic Mediterranean Barbus and Luciobarbus species and to the widely distributed European Barbus barbus, as previously shown by molecular phylogenetic studies of cyprinid fishes [43, 45, 47, 72], i.e. Dactylogyrus omenti n. sp. from $A$. huegelii was nested within Dactylogyrus spp. from Barbus species. Dactylogyrus vastator clustered with $D$. extensus from $C$. carpio and with $D$. anchoratus from C. gibelio. This clade was well separated from the clade of Dactylogyrus species parasitizing Barbus, Luciobarbus and $A$. huegelii. By comparing the genetic distances of $D$. vastator specimens from different hosts using the sequences of partial 18S and the ITS1 regions (Table 3), we conclude that $D$. vastator from $A$. huegelii is genetically identical to $D$. vastator collected from C. gibelio from Croatia and Barbus

Table 1 Basic epidemiological data for Dactylogyrus species collected from A. huegelii

\begin{tabular}{llll}
\hline Species & $P(\%)$ & MA & 1 \\
\hline D. vastator & 29 & 0.3 & 1 \\
D. omenti n. sp. & 93 & 3.4 & $1-8$ \\
\hline
\end{tabular}

Abbreviations: $P$, prevalence; $M A$, mean abundance, $l$, intensity of infection 


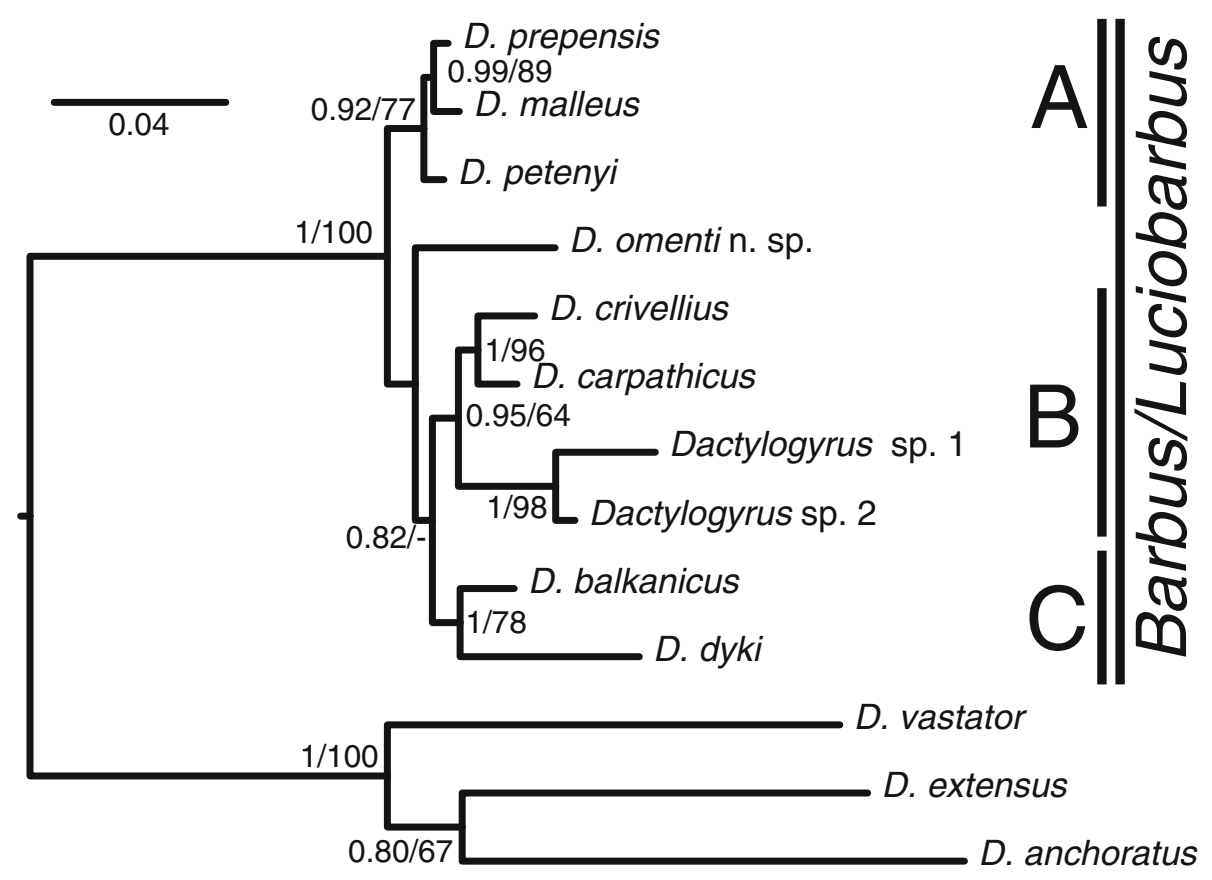

Fig. 1 Phylogenetic tree constructed by Bayesian Inference (BI) analysis. The tree is based on concatenated data of partial 185 and ITS1 rDNA sequences with partial 28S rDNA sequences for selected Dactylogyrus species. Values along branches indicate BI posterior probabilities and Maximum Likelihood (ML) bootstrap values as BI/ML. Values $<0.80$ for BI and $<50 \%$ for $\mathrm{ML}$ are indicated by dashes or not shown. Length of branches corresponds to the expected number of substitutions per site. Groups A, B and C refer to the different lineages of Dactylogyrus species parasitizing European Barbus and Luciobarbus species

plebejus Bonaparte, 1839 from Italy. In comparison to species collected in central Europe and eastern Asia, D. vastator from $A$. huegelii is closer to $D$. vastator of $C$. carpio (p-distance $=0.003$ ) than to $D$. vastator of $C$. gibelio from the Czech Republic or to D. vastator of C. auratus from China (p-distance $>0.043$ ).

Dactylogyrus species recovered from Barbus spp. formed a paraphyletic group with the nested position of Dactylogyrus spp. from Greek Luciobarbus and D. omenti n. sp. Three well- (or moderately-) supported groups were recognized for Dactylogyrus species collected from Barbus and Luciobarbus hosts (Fig. 1). Group A (PP $=0.92$, BS $=77$ ) comprised D. prespensis Dupont \& Lambert, 1986, D. malleus Linstow, 1877 and D. petenyi Kastak, 1957, which exhibit a similar shape of the male copulatory organ (MCO). Group B was formed by two well supported clades, the first including D. carpathicus Zachvatkin, 1951 and $D$. crivellius Dupont \& Lambert, 1986 collected from Barbus, and the second including two undescribed species Dactylogyrus sp. 1 and Dactylogyrus sp. 2 collected from Greek Luciobarbus. All these species exhibit a similar shape of the haptoral hard parts, especially in having a cross-shaped connective ventral bar with 5 marginal extremities, but differ between clades in the shape of the MCO. The last supported grouping (group $\mathrm{C}$ in Fig. $1, \mathrm{PP}=1, \mathrm{BS}=78$ ) comprised D. balkanicus Dupont \& Lambert, 1986 and $D$. dyki Ergens \& Lucky, 1959. While D. dyki is a widely distributed European species (i.e. infecting a wide range of Barbus spp.), D. balkanicus appears to be endemic to the Balkan Peninsula, and they both share a similar shape of the MCO. Dactylogyrus omenti n. sp. was found at the basal position in the group of Dactylogyrus species parasitizing Barbus and Luciobarbus. However, the phylogenetic position of D. omenti n. sp. in relation to Dactylogyrus groups $\mathrm{A}, \mathrm{B}$ and $\mathrm{C}$ was not resolved.

\section{Family Dactylogyridae Bychowsky, 1933 Genus Dactylogyrus Diesing, 1850}

\section{Dactylogyrus omenti n. sp.}

Type-host: Aulopyge huegelii Heckel, 1843 (Cypriniformes: Cyprinidae).

Type-locality: Locality Duvansko polje, River Šujica, Bosnia and Herzegovina ( $\left.43^{\circ} 42^{\prime} 05.7^{\prime \prime} \mathrm{N}, 17^{\circ} 15^{\prime} 50.5^{\prime \prime} \mathrm{E}\right)$.

Type-material: The holotype, 4 paratypes, 1 hologenophore and 3 paragenophores are deposited under the accession number IPCAS M-629.

Site on host: Gill lamellae.

Representative DNA sequences: A nucleotide sequence of partial 28S rDNA (791 bp long; KY201105) and nucleotide sequences representing a fragment (939 bp long; 


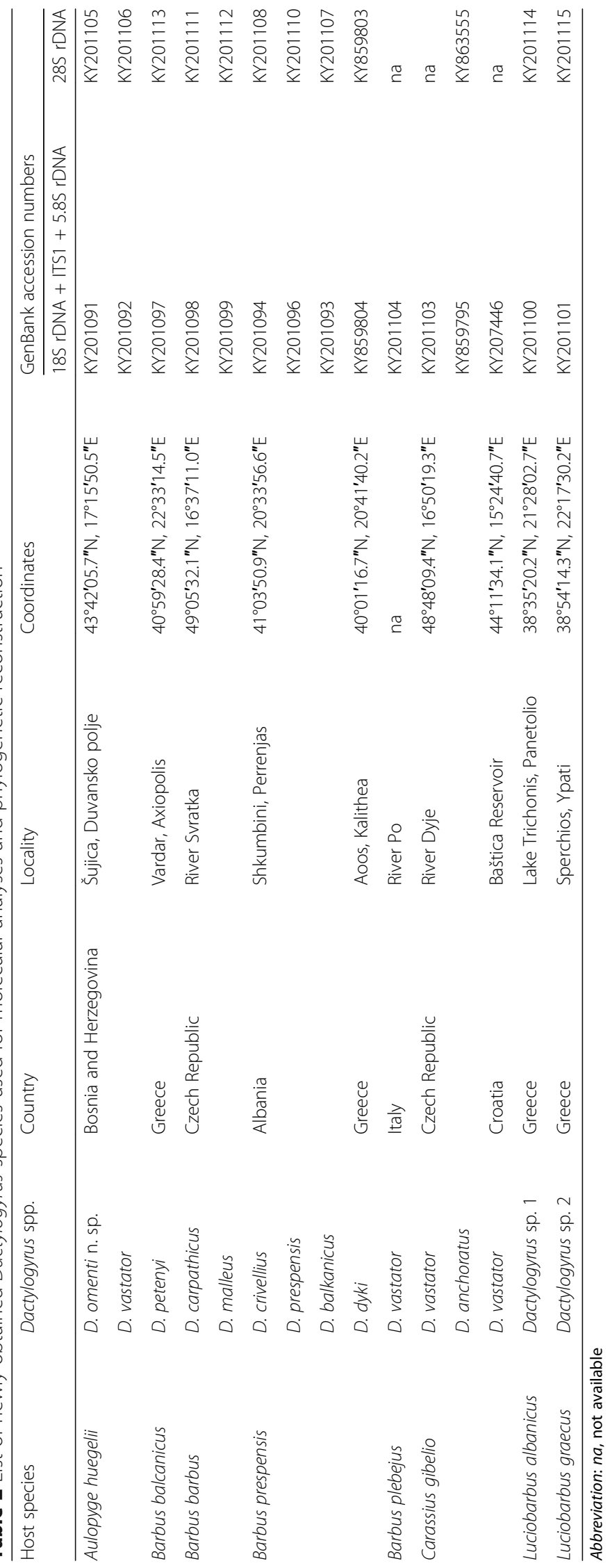


Table 3 Uncorrected pairwise distances between sequences for D. vastator collected from Aulopyge huegelii and different species of Cyprininae

\begin{tabular}{|c|c|c|c|c|c|c|c|c|}
\hline \multicolumn{2}{|c|}{ Host species $^{\mathrm{a}}$} & \multirow{2}{*}{$\begin{array}{l}\text { Locality } \\
\text { River Šujica, Bosnia and Herzegovina }\end{array}$} & \multirow{2}{*}{$\begin{array}{ll}2 \\
0.000\end{array}$} & \multirow{2}{*}{$\begin{array}{ll}3 \\
0.001\end{array}$} & \multirow{2}{*}{$\begin{array}{ll}4 \\
0.042\end{array}$} & \multirow{2}{*}{$\begin{array}{ll}5 \\
0.042\end{array}$} & \multirow{2}{*}{$\begin{array}{ll}6 \\
0.047\end{array}$} & \multirow{2}{*}{$\frac{7}{0.004}$} \\
\hline 1 & Aulopyge huegelii (KY201091) & & & & & & & \\
\hline 2 & Barbus plebejus (KY201104) & River Po, Italy & & 0.001 & 0.042 & 0.042 & 0.047 & 0.004 \\
\hline 3 & Carassius gibelio (KY207446) & Baštica, Croatia & & & 0.043 & 0.043 & 0.048 & 0.003 \\
\hline 4 & Carassius gibelio (KY201103) & River Dyje, Czech Republic & & & & 0.002 & 0.004 & 0.047 \\
\hline 5 & Carassius auratus (KJ854363) & Nanyang, Henan, China & & & & & 0.004 & 0.047 \\
\hline 6 & Carassius auratus (KM487695) & River Ergis, China & & & & & & 0.051 \\
\hline 7 & Cyprinus carpio (AJ564159) & River Morava, Czech Republic & & & & & & \\
\hline
\end{tabular}

${ }^{\mathrm{a} G e n B a n k}$ accession numbers included

Genetic distances were calculated using the sequences of partial 18S rDNA and ITS1 (see Table 2 for accession numbers for D. vastator sequences generated in this study)

KY201091) including partial 18S rDNA (446 bp), the ITS1 region (493 bp) and $5.8 \mathrm{~S}(6 \mathrm{bp})$. No intraspecific variability was found (6 specimens were analyzed).

ZooBank registration: To comply with the regulations set out in article 8.5 of the amended 2012 version of the International Code of Zoological Nomenclature (ICZN) [73], details of the new species have been submitted to ZooBank. The Life Science Identifier (LSID) of the article is urn:lsid:zoobank.org:pub:723FC725-1C88-4DF6-8ECE-AD C1EE658F8B. The LSID for the new name Dactylogyrus omenti is urn:lsid:zoobank.org:act:697DD685-1B87-4FB4B3CA-65000EC772FF.

Etymology: The specific name is derived from Latin (omentum $=$ membrane, bowels) and refers to the shape of the accessory piece.

\section{Description}

[Based on 13 specimens in GAP; Figs. 2 and 3.] Body length 230-522 (362; $n=3)$, with greatest width 57-128 $(95 ; n=3)$, usually near mid-length. One pair of anchors

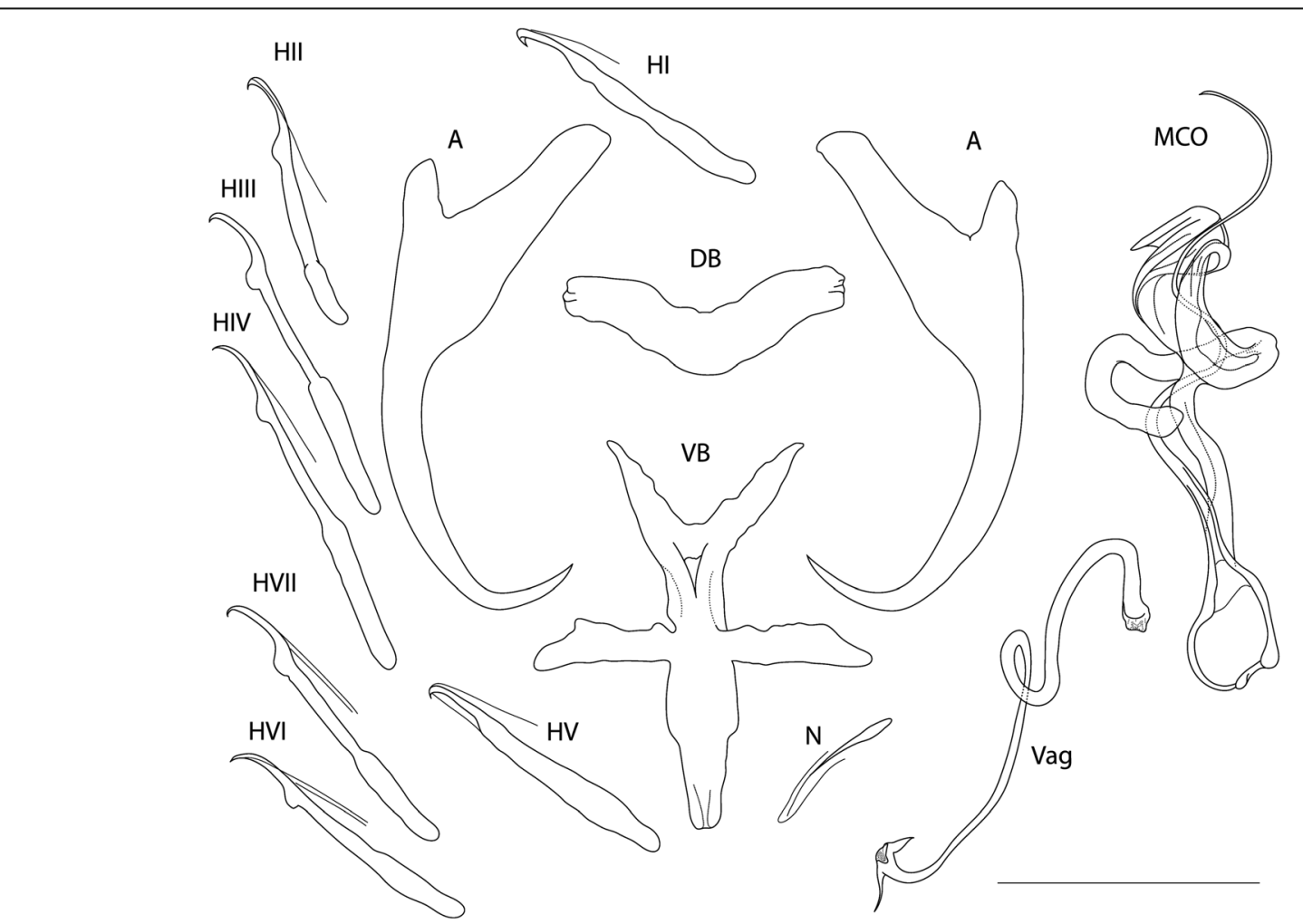

Fig. 2 Drawings of hard parts of haptor and reproductive organs of Dactylogyrus omenti n. sp. Abbreviations: A, anchors; DB, dorsal connective bar; VB, ventral connective bar; H, marginal hooks (pairs I-VII); N, needle; MCO, male copulatory organ; Vag, vagina. Scale-bar: $20 \mu \mathrm{m}$ 


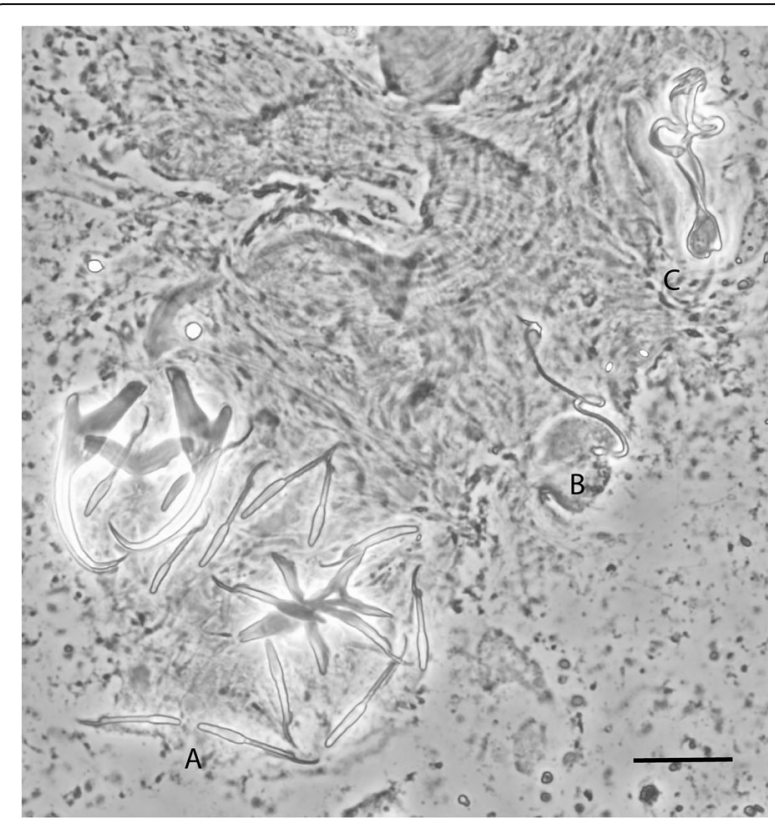

Fig. 3 Phase contrast photomicrograph of hard parts of Dactylogyrus omenti n. sp. Abbreviations: A, haptor; B, vagina; C, male copulatory organ. Scale-bar: $20 \mu \mathrm{m}$

(dorsal), inner length $37-41(38 ; n=10)$, outer length $34-$ $37(35 ; n=10)$. Inner root long, extending to broader base in its medial part, $11-16(14 ; n=10)$; outer root short, slightly pointed outward, $3-6(5 ; n=10)$, with moderately curved shaft and short turned-in point, 6-7 $(6 ; n=10)$. Dorsal bar saddle-shaped, with subterminal folding, total length $21-23(22 ; n=10)$, total width $4-5(4 ; n=10)$. Ventral bar airplane shaped, five-pointed, total length 28$31(30 ; n=10)$, total width $22-27(24 ; n=10)$; Marginal hooks 7 pairs, dissimilar in size, each with delicate point, long shaft with expanded proximal subunit; filament loop partial, reaching close to level of expanding part of shaft. Hook lengths $(n=10)$ : pair I 21-22 (21), pair II 19-24 (21), pair III 22-26 (25), pair IV 25-32 (28), pair V 21-23 (22), pair VI 20-24 (22), pair VII 22-28 (24). One pair of needles located near marginal hooks of pair $\mathrm{V}$, length $11-12(12 ; n=10)$. Vagina sclerotized, elongated, usually twisted tube, with anchor shaped opening (opens dextrally), trace length $54-62(56 ; n=10)$. MCO comprising basally articulated copulatory tube and accessory piece, total length $34-38(36 ; n=10)$. Copulatory tube delicate, undulated in its medial part, distally narrowing to non-enveloped termination, tube-trace length 45-54 (49; $n=10)$; with thick-walled base, length 8-10 $(8 ; n=10)$, width $6-7(6 ; n=10)$. Accessory piece passing to colon-shaped process encircling medial part of copulatory tube, in distal portion and shield-like membranous broadening supporting copulatory tube.

\section{Remarks}

According to the morphology of the haptoral hard parts and reproductive organs, $D$. omenti $\mathrm{n}$. sp. is most similar to Dactylogyrus affinis Bychowsky, 1933 (recorded from Barbus lacerta Heckel, 1843 [74], Luciobarbus brachycephalus (Kessler, 1872) [75], L. capito (Güldenstädt, 1773) [76] and L. xanthopterus Heckel, 1843 [77]), Dactylogyrus deziensioides Gussev, Jalali \& Molnar, 1993 (from L. kersin Heckel, 1843 [78]), and Dactylogyrus crivellius (from B. prespensis) [48, 79]. However, D. omenti n. sp. differs from these species by the size of its haptoral hard parts, which are smaller (comparative morphometric data are provided in Table 4). In general, the configuration of hard haptoral elements and the shape of the ventral bars also resembles Dactylogyrus spp. from Moroccan Luciobarbus spp. described by el Gharbi et al. [80]. The MCO of $D$. omenti n. sp. most closely resembles the MCO of $D$. deziensioides, due to the presence of the colonshaped process of the accessory piece encircling the copulatory tube. However, the copulatory tube of $D$. deziensioides is massive and short, in contrast with the delicate and long copulatory tube of $D$. omenti n. sp. In the original description of D. affinis, Bychowsky [81] pointed out the poor visibility of the end of copulatory tube, because of a saucer-shaped broadening of the accessory piece. This observation corresponds with the poor visibility of the medial part of the copulatory tube of $D$. omenti n. sp., on account of the shield-like broadening. Nevertheless, the colonshaped process of the accessory piece is missing in the original drawing of $D$. affinis. The elongated twisted vagina of $D$. affinis markedly resembles the shape of the vagina of $D$. omenti n. sp. In regards to $D$. crivellius, $D$. omenti n. sp. differs in having a longer copulatory tube, larger colon-shaped part of the accesory piece and a thinner and longer vagina.

\section{Discussion}

With two species now known, the overall species richness of Dactylogyrus from A. huegelii is similar to that of other Barbus species from southern (France and Spain) and central Europe, for which 1-3 Dactylogyrus species per host species have been documented [25, 82]. The species richness of Dactylogyrus from Barbus species in the Balkan Peninsula ranges between 1 and 5 Dactylogyrus species per host species [e.g. 48]. While endemic and widely distributed Barbus species share several Dactylogyrus species (such as D. dyki, D. petenyi, D. crivellius, D. carpathicus, D. malleus and D. balkanicus), D. omenti n. sp. was recognized only from $A$. huegelii in this study, and therefore it is likely specific for this cyprinid species.

Dactylogyrus vastator, the parasite species with a large body size, has been widely reported from wild and farmed populations of $C$. carpio and Carassius spp., both of which belong to the subfamily Cyprininae (e.g. [52, 83-86]). In addition, the accidental infection of $D$. vastator was also 
Table 4 Comparative metrical data (in $\mu \mathrm{m}$ ) for hard parts of the haptor and reproductive organs of $D$. omenti n. sp. and morphologically similar Dactylogyrus spp.

\begin{tabular}{|c|c|c|c|c|c|}
\hline Character & & D. omenti n. sp. & D. affinis & D. deziensioides & D. crivellius \\
\hline \multirow[t]{2}{*}{ Body } & length & $230-522$ & $600^{\mathrm{a}}$ & $470^{a}$ & - \\
\hline & width & $57-128$ & $160^{\mathrm{a}}$ & $120^{\mathrm{a}}$ & - \\
\hline \multirow[t]{5}{*}{ Anchors } & inner length & $37-41$ & $46-65$ & $47-49$ & $58-61$ \\
\hline & outer length & $34-37$ & $39-50$ & $35-37$ & $49-52$ \\
\hline & inner root length & $11-16$ & $12-21$ & $16-17$ & $19-20$ \\
\hline & outer root length & $3-6$ & $3-6$ & $5-6$ & $7-8$ \\
\hline & point length & $6-7$ & $12-15$ & $12-14$ & $17-18$ \\
\hline \multirow[t]{2}{*}{ Ventral bar } & length & $28-31$ & $50^{a}$ & $43-47$ & $42^{\mathrm{a}}$ \\
\hline & width & $22-27$ & $34^{\mathrm{a}}$ & $30-32$ & $26^{\mathrm{a}}$ \\
\hline \multirow[t]{2}{*}{ Dorsal bar } & length & $21-23$ & $36-46$ & $33^{\mathrm{a}}$ & $42-43$ \\
\hline & width & $4-5$ & $4-8$ & $3-4$ & $9^{a}$ \\
\hline Marginal hooks & length & $19-32$ & $21-33$ & $25-28$ & $31-34$ \\
\hline Needle & length & $11-12$ & - & - & - \\
\hline $\mathrm{MCO}$ & length & $34-38$ & $37-47$ & $46^{a}$ & $58-62$ \\
\hline Vagina & length & $54-62$ & $40-50$ & - & - \\
\hline
\end{tabular}

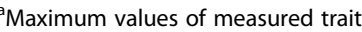

Measurements of $D$. affinis, D. deziensioides and D. crivellius are obtained from [91]

found on some other cyprinid species (especially on Barbus [13], M. Benovics, unpublished data). Our study revealed a moderate prevalence of $D$. vastator on $A$. huegelii, which indicates that the infection of $D$. vastator on this endemic cyprinid species is not an accident. However, the low parasite infrapopulation size may indicate that this host is probably not suitable for maintaining parasite populations. Cyprinus carpio and C. gibelio may harbour up to nine different Dactylogyrus species [25, 87, 88]. The presence of only $D$. vastator on $A$. huegelii from this wide range of Dactylogyrus species could indicate: (i) the absence of other Dactylogyrus spp. on C. carpio and Carassius species potentially living in sympatry with $A$. huegelii; (ii) strict host specificity among other Dactylogyrus spp. of C. carpio and C. gibelio resulting from reciprocal coadaptation; or (iii) different morphologies of gill filaments providing microhabitats suitable for some Dactylogyrus species (i.e. large species such as $D$. vastator or $D$. extensus), but unsuitable for others (i.e. small species such as $D$. achmerowi Gussev, 1955, D. falciformis Akhmerov, 1952 or D. minutus Kulwiec, 1927). To test these hypotheses, further investigation of parasite communities on C. carpio and Carassius spp. potentially living in sympatry with $A$. huegelli and analyses of the niche preferences of Dactylogyrus parasites (i.e. the preferred positions on fish gills) are necessary. Dactylogyrus vastator usually infects small fingerlings, where overpopulation may result in the mortality of the host. According to Uspenskaya [89], 40 specimens of $D$. vastator could possibly cause the death of a fish with a body length of $2 \mathrm{~cm}$. This is not the case with $A$. huegelii, where very low abundance was found, i.e. only a single specimen of $D$. vastator per individual fish, suggesting that mortality of this host is unlikely. This low abundance is conflicting with optimal conditions for the development of this parasite species [90, 91], because high population growth and consequently a high intensity of infection on the part of $D$. vastator are expected in southern regions, which have high water temperatures in summer. Possible explanations could be that the mobility of $D$. vastator larvae is restricted by different suboptimal environmental factors, resulting from the habitat preference of $A$. huegelii; that is, finding new hosts in these conditions may be more difficult. Alternatively, this species could be competitively excluded by higher populations of the second host-specific species parasitizing A. huegelii, Dactylogyrus omenti n. sp. [79, 92], which, in our study, was the most abundant Dactylogyrus species on A. huegelli.

We hypothesized that Dactylogyrus species are a good indicator of evolutionary relationships between cyprinid host species. Despite the low abundance of D. vastator on $A$. huegelii, this record supports the phylogenetic relationships of $A$. huegelii to species of the Cyprininae originating from Asia and probably introduced into Europe, i.e. C. carpio and Carassius spp. This parasite species was also found in very low abundance ( 1 specimen per fish and a prevalence of 20\%) on Barbus plebejus during our field study in Italy. Aulopyge huegelii possibly offers a similar type of substrate, which, in the case of Dactylogyrus spp., is gill filaments, and, therefore, common Dactylogyrus spp. parasitizing C. carpio and Carassius species [83, 85, 88, 93] can also develop and inhabit closely phylogenetically related species such as A. huegelii and some Barbus species. This 
may support the finding of Shamsi et al. [88] indicating that the transmission of $D$. anchoratus from common carp to Barbus sharpeyi, an important native fish species, takes place despite the high host specificity of many Dactylogyrus species. Šimková et al. [25] proposed that the phylogeny of Dactylogyrus reflects, at least partially, the phylogeny of their cyprinid host species (depending more or less on the level of host specificity of particular species). According to Kohlmann et al. [94], European and Asian cyprinids share a common ancestor from central Eurasia. While C. carpio is widely distributed in the Eurasian region, species of the $C$. auratus complex are native to eastern Asia and were only recently imported into Europe and other continents $[26,95]$. There are no paleontological records of the $C$. auratus complex in Europe before the Pleistocene [95]. By computing pairwise genetic distances between $D$. vastator from different host species, we showed that $D$. vastator of $A$. huegelii collected in Bosnia and Herzegovina was genetically identical with $D$. vastator of $C$. gibelio from Croatia and Barbus plebejus collected in Italy. Moreover, this form of $D$. vastator appears to be evolutionarily closer to $D$. vastator collected from $C$. carpio than to $D$. vastator from C. auratus and C. gibelio from central Europe. However, as we have only limited data on the distribution of D. vastator in C. carpio or Carassius spp., and no data on the distribution and origin of these fish species in Mediterranean areas (the Apennine and Balkan Peninsulas), this may indicate two scenarios of historical dispersion of D. vastator: (i) D. vastator occurring in endemic Mediterranean fishes originated from the historical dispersion of C. carpio to the Mediterranean Peninsulas, where former population of D. vastator parasitizing non-native $C$. carpio switched to phylogenetically related Mediterranean cyprinid species and introduced C. gibelio, and then slightly genetically differentiated from the former population; (ii) Genetic differentiation took place among geographically isolated populations of D. vastator parasitizing C. carpio and the representatives of $C$. auratus complex, and the genetically differentiated form of $D$. vastator was, with their non-native hosts (probably with C. gibelio), introduced more recently to different Mediterranean Peninsulas and switched to phylogenetically related endemic Mediterranean cyprinids. Both scenarios may suggest the potential risk of $D$. vastator infection for endemic cyprinids. Data on the infection levels of D. vastator in non-native C. carpio and C. gibelio in Mediterranean areas may be helpful to clarify whether endemic cyprinids serve as real or accidental host species for this species. Unfortunately, such data are not at disposal in this study.

The phylogenetic position of $D$. omenti $\mathrm{n}$. sp. was found to be nested within Dactylogyrus of Barbus and Luciobarbus. The morphological similarity between the copulatory organs and haptoral hard parts of $D$. omenti $\mathrm{n}$. sp. and $D$. affinis and
D. deziensioides indicates the potentially earlier diversion of the newly described species from species parasitizing Barbus and Luciobarbus species from Kazakhstan, Turkey and Middle East. This supports the close phylogenetic affinity of $A$. huegelii with ancestral Barbus lineages of Asia, from which $A$. huegelii and European Barbus lineages supposedly emerged [43]. Unfortunately, the lack of molecular data for $D$. affinis and $D$. deziensioides makes further examination of evolutionary connections currently impossible. With the shape of its haptoral hard elements, especially its typical cross-shaped ventral bar with five extremities, D. omenti n. sp. resembles Dactylogyrus of Greek and Moroccan Luciobarbus (see [80] for their morphology) and also $D$. carpathicus and D. crivellius from widely distributed Barbus species [48, 82]. It was suggested that the shape of the haptoral hard parts appears to be more suitable for resolving phylogenetic relationships between lineages of a given monogenean genus, while the shape of the reproductive organs is more suitable for identification at the species level because of its faster evolutionary change [23, 96-99]. This may indicate that $D$. omenti $\mathrm{n}$. sp. is evolutionarily closer to the earlier mentioned species than to other Dactylogyrus of Barbus, possessing a different type of ventral bar. Nevertheless, our results showed that four Dactylogyrus spp. with a crossshaped ventral bar with 5 extremities, i.e. $D$. crivellius, $D$. carpathicus, Dactylogyrus sp. 1 and Dactylogyrus sp. 2 (clade B in Fig. 1), formed a well supported ( $\mathrm{PP}=0.95$, $\mathrm{BS}=64)$ monophyletic group to the exclusion of $D$. omenti $\mathrm{n}$. sp. The unexpected phylogenetic position of $D$. omenti $\mathrm{n}$. sp. indicates that using only the shape of the haptor as a marker for solving phylogenetic relationships in monogenean species with rapid diversification is not advisable and that the shape of the reproductive organs should be taken into account. However, the phylogenetic relationships between other Dactylogyrus species included in our phylogenetic reconstruction follow haptor morphology, specifically the shape of the connective bars and hooks. This is true of the monophyletic group of $D$. balkanicus and D. $d y k i$ (group C), which possess a similar shape of hard parts of attachment organ (anchors, connective bars and marginal hooks) [48], though the two species vary in the dimensions of their haptoral hard parts [79]. Additionally, the copulatory organ of both species is similar. The fast development of variations in reproduction organs is considered as a mechanism for avoiding hybridization in the case of multiple congeneric monogenean species living in overlapping microhabitats [100]. This is also true for Dactylogyrus species parasitizing Barbus. Of a possible seven Dactylogyrus spp., Barbus and Luciobarbus species usually harbour only Dactylogyrus species with copulatory organs of a markedly different shape, representing different phylogenetic lineages $([80,92,101]$. For instance, as is shown in the present study, B. prespensis 
hosts four species with differently shaped copulatory organs, D. balkanicus, D. crivellius, D. dyki and D. prespensis, representing three different phylogenetic lineages (see Table 2 and Fig. 1). Also the morphologically similar and phylogenetically close species, such as $D$. dyki and $D$. balkanicus, were not present on the same host species in one population.

\section{Conclusions}

Dactylogylrus omenti $\mathrm{n}$. sp. was recognized as a potentially strict specialist of $A$. huegelii. Concluding from the expected high degree of host specificity of Dactylogyrus parasites and presence of $D$. vastator, a typical parasite of C. carpio and Carassius spp., on A. huegelii, or the phylogenetic position of $D$. omenti n. sp., the $A$. huegelii is a taxon closely related to European Barbus and Luciobarbus and to the Cyprininae of Asian origin. Regarding hard morphological characters, D. omenti n. sp. resembles species of Dactylogyrus parasitizing species of Barbus and Luciobarbus from the Middle East and Kazakhstan. Similarities in the shape of hard parts may suggest the origin of $D$. omenti $\mathrm{n}$. $\mathrm{sp}$. in this region and also an evolutionary proximity of endemic Cyprininae from the Middle East and Kazakhstan to A. huegelii. The genetic distances between $D$. vastator collected from different host species revealed that $D$. vastator in $A$. huegelii is identical with $D$. vastator of Balkan $C$. gibelio and closer to the central European C. carpio rather than to $C$. auratus complex. These results are indicating recent host switch of $D$. vastator between different hosts in Europe. The phylogenetic reconstruction of Dactylogyrus species parasitizing different endemic Barbus spp. and Luciobarbus spp. in the Balkan Peninsula and widely distributed European Barbus spp. revealed that, despite the generally accepted view that the morphology of the attachment organ is the best tool for resolving phylogenetic relations (based on morphological characters only) between Dactylogyrus species, the shape and size of the copulatory organs of rapidly evolving monogeneans have to be taken into consideration. But most importantly, only the combination of both morphological characters together with molecular data should be used for resolving the phylogeny and detection of potentially hidden diversity.

\section{Abbreviations}

BI: Bayesian inference analysis; BS: Bootstrap values resulting from maximum likelihood analysis; GAP: Mixture of glycerine and ammonium picrate; MC $^{3}$ : Metropolis-coupled Markov chain Monte Carlo analysis; MCO: Male copulatory organ; ML: Maximum likelihood analysis; PP: Posterior probability resulting from Bayesian inference analysis

\section{Acknowledgements}

We are grateful to Jasna Vukić, Charles University in Prague, and Radek Šanda from the National Museum, Prague, for fish collection. We thank Jaroslav Červenka and Petra Zahradníčková for their help with fish dissection and parasite collection. We kindly thank Matthew Nicholls for English revision of the final draft and two anonymous reviewers for constructive suggestions and comments.

\section{Funding}

This study was funded by Czech Science Foundation (project No. 15-19382S).

Availability of data and materials

The data supporting the conclusions of this study are included in this article. The type-material of the new species described in this study was deposited in the Helminthological Collection of the Institute of Parasitology, Czech Academy of Sciences, České Budĕjovice, Czech Republic under the accession number IPCAS M-629. The newly generated sequences were submitted to the GenBank database (accession numbers are detailed in Table 2).

\section{Authors' contributions}

AŠ designed and supervised the study and organised the field trip and parasite collection. AŠ, MB and MLK processed fish and collected parasites during the field trip. MB and MLK performed microscopical observations and identified new species. MLK drew the hard parts and wrote the description of the new species. MB performed all laboratory procedures and

phylogenetic analyses. AŠ performed statistical analyses. $A \breve{S}$ and $M B$ wrote the draft of the paper and discussed the results. A $\breve{S}$ revised the manuscript. All authors read and approved the final manuscript.

\section{Ethics approval}

All applicable institutional, national and international guidelines for the care and use of animals were followed. This study was approved by the Animal Care and Use Committee of the Faculty of Science, Masaryk University in Brno (Czech Republic)

\section{Consent for publication}

Not applicable.

\section{Competing interests}

The authors declare that they have no competing interests.

\section{Publisher's Note}

Springer Nature remains neutral with regard to jurisdictional claims in published maps and institutional affiliations.

Received: 6 December 2016 Accepted: 23 October 2017

Published online: 03 November 2017

References

1. de Vienne DM, Refrégier G, López-Villavicencio M, Tellier A, Hood ME, Giradud T. Cospeciation vs host-shift speciation: methods for testing, evidence from natural associations and relation to coevolution. New Phytol. 2013;198:347-85.

2. Sasal P, Trouvé S, Müller-Graf C, Morand S. Specificity and host predictability: a comparative analysis among monogenean parasites of fish. J Anim Ecol. 1999;68:437-44.

3. Timms R, Read AF. What makes a specialist special? Trends Ecol Evol. 1999; 14:333-4.

4. Randhawa HS, Burt MDB. Determinants of host specificity and comments on attachment site specificity of tetraphyllidean cestodes infecting rajid skates from the northwest Atlantic. J Parasitol. 2008;94:436-61.

5. Paterson AM, Gray RD, Wallis GP. Parasites, petrels and penguins: does louse presence reflect seabird phylogeny? Int J Parasitol. 1993;23:515-26.

6. Ronquist F. Phylogenetic approaches in coevolution and biogeography. Zool Scr. 1998;26:313-22.

7. Desdevises Y, Morand S, Legendre P. Evolution and determinants of host specificity on the genus Lamellodiscus (Monogenea). Biol J Linn Soc. 2002; 77:431-43.

8. McDowall RM. Biogeography of the southern cool-temperate galaxoid fishes: evidence from metazoan macroparasite faunas. J Biogeogr. 2000;27: 1221-9.

9. Šimková A, Morand S. Co-evolutionary patterns in congeneric monogeneans: a review of Dactylogyrus species and their cyprinid hosts. J Fish Biol. 2008;73: 2210-27.

10. Mendlová M, Šimková A. Evolution of host specificity on monogeneans parasitizing African cichlid fish. Parasit Vectors. 2014;7:69. 
11. Vanhove MPM, Pariselle A, Van Steenberge M, Raeymaekers JAM, Hablütze PI, Gillardin C, et al. Hidden biodiversity in an ancient lake: phylogenetic congruence between Lake Tanganyika tropheine cichlids and their monogenean flatworm parasites. Sci Rep. 2015;5:13669.

12. Poulin R, Mouilott D. Parasite specialization from phylogenetic perspective: a new index of host specificity. Parasitology. 2003;126:473-80.

13. Gibson DI, Timofeeva TA, Gerasev PI. Catalogue of the nominal species of the monogeneans of genus Dactylogyrus Diesing, 1850 and their host genera. Syst Parasitol. 1996;35:3-48.

14. Šimková A, Matějusová I, Cunningham COA. Molecular phylogeny of the Dactylogyridae sensu Kritsky \& Boeger (1989) (Monogenea) based on the D1-D3 domains of large subunit rDNA. Parasitology. 2006;133:43-53.

15. Buchmann K, Lindenstrøm T. Interactions between monogenean parasites and their fish hosts. Int J Parasitol. 2002;32:309-19.

16. Kearn GC. Evolutionary expansion of the Monogenea. Int J Parasitol. 1994; 24:1227-71.

17. Buchmann K. Immune mechanisms in fish against monogeneans - a model. Folia Parasitol. 1999;46:1-9.

18. Desdevises Y. Cophylogeny: insights from fish-parasite systems. Parassitologia. 2007:49:125-8.

19. Whittington ID, Kearn GC. Hatching strategies in monogenean (platyhelminth) parasites that facilitate host infection. Integr Comp Biol. 2011:51:91-9.

20. Kadlec D, Šimková A, Gelnar M. The microhabitat distribution of two Dactylogyrus species parasitizing the gills of the barbel, Barbus barbus. J Helminthol. 2003;77:317-25.

21. Šimková A, Desdevises Y, Gelnar M, Morand S. Co-existence of nine gill ectoparasites (Dactylogyrus: Monogenea) parasitising the roach (Rutilus rutilus L.): history and present ecology. Int J Parasitol. 2000;30:1077-88.

22. Šimková A, Desdevises Y, Gelnar M, Morand S. Morphometric correlates of host specificity in Dactylogyrus species (Monogenea) parasites of European cyprinid fish. Parasitology. 2001;123:169-77.

23. Šimková A, Verneau O, Gelnar M, Morand S. Specificity and specialization of congeneric monogeneans parasitizing cyprinid fish. Evolution. 2006;60: 1023-37.

24. Matějusová I, Šimková A, Sasal P, Gelnar M. Microhabitat distribution of Pseudodactylogyrus anguillae and Pseudodactylogyrus bini among and within gill arches of the European eel (Anguilla anguilla L). Parasitol Res. 2003;89: 260-9.

25. Šimková A, Morand S, Jobet E, Gelnar M, Verneau O. Molecular phylogeny of congeneric monogenean parasites (Dactylogyrus): a case of intrahost speciation. Evolution. 2004;58:1001-18.

26. Kottelat M, Freyhof J. Handbook of European freshwater fishes. Cornol: Publications Kottelat; 2007

27. Oikonomou A, Leprieur F, Leonardos ID. Biogeography of freshwater fishes of the Balkan Peninsula. Hydrobiologia. 2014;738:205-20.

28. Sušnik S, Snoj A, Wilson IF, Mrdak D, Weiss S. Historical demography of brown trout (Salmo trutta) in the Adriatic drainage including the putative $S$. letnica endemic to Lake Ohrid. Mol Phylogenet Evol. 2007:44:63-76.

29. Abell R, Thieme ML, Revenga C, Bryer M, Kottelat M, Bogutskaya N, et al. Freshwater ecoregions of the world: a new map of biogeographic units for freshwater biodiversity conservation. J. Bioscience. 2008:58:403-14.

30. Albrecht C, Wilke T. Ancient Lake Ohrid: biodiversity and evolution. Hydrobiologia. 2008;615:103-40.

31. Schulthess R, Albrecht C, Bossneck U, Wilke T. The neglected side of speciation in ancient lakes: phylogeography of an inconspicuous mollusc taxon in lakes Ohrid and Prespa. Hydrobiologia. 2008;615:141-56.

32. Wagner B, Wilke T. Evolutionary and geological history of the Balkan lakes Ohrid and Prespa. Biogeosciences. 2011;8:995-8.

33. Zardoya R, Economidis PS, Doadrio I. Phylogenetic relationships of Greek Cyprinidae: molecular evidence for at least two origins of the Greek cyprinid fauna. Mol Phylogenet Evol. 1999;13:122-31.

34. Economidis PS, Banarescu PM. The distribution and origin of freshwater fishes in the Balkan peninsula, especially in Greece. Int Rev Hydrobiol. 1991; 76:257-83.

35. Imsiridou A, Apostolidis A, Durand JD, Briolay J, Bouvet Y, Triataphyllidis C Genetic differentiation and phylogenetic relationships among Greek chub Leuciscus cephalus L. (Pisces, Cyprinidae) populations revealed by RFLP analysis of mitochondrial DNA. Biochem Syst Ecol. 1998;26:415-29.

36. Durand JD, Templeton AR, Guinand B, Imsiridou A, Bouvett Y. Nested clade and phylogenetic analyses of the chub Leuciscus cephalus (Teleostei,
Cyprinidae), in Greece: implications for Balkan Peninsula biogeography. Mol Phylogenet Evol. 1999;13:566-80.

37. Ketmaier V, Bianco PG, Coboli M, Krivokapic M, Caniglia R, De Matthaeis E. Molecular phylogeny of two lineages of Leuciscinae cyprinids (Telestes and Scardinius) from peri-Mediterranean area based on cytochrome $b$ data. Mol Phylogenet Evol. 2004;32:1061-71.

38. Marková S, Šanda R, Crivelli A, Shumka S, Wilson IF, Vukić J, et al. Nuclear and mitochondrial DNA sequence data reveal the evolutionary history of Barbus (Cyprinidae) in the ancient lake systems of the Balkans. Mol Phylogenet Evol. 2010;55:488-500.

39. Palandačíc A, Bravničar J, Zupančič P, Šanda R, Snoj A. Molecular data suggest a multicpecies complex of Phoxinus (Cyprinidae) in the western Balkan peninsula. Mol Phylogenet Evol. 2015:92:118-23.

40. Stierandová S, Vukić J, Vasil'eva ED, Zogaris S, Shumka S, Halačka K, et al. A multilocus assessment of nuclear and mitochondrial sequence data elucidates phylogenetic relationships among Eruopean spirlins (Alburnoides, Cyprinidae). Mol Phylogenet Evol. 2016;94:479-91.

41. Vuković T, Ivanović B. Freshwater fishes of Yugoslavia. Zemaljski Muzej: Sarajevo; 1971.

42. Mrakovčić M, Mišetić S. Status, distribution and conservation of the salmonid, Salmothymus obtusirostris (Heckel) and the cyprinid, Aulopyge hugeli (Heckel) in Yugoslavia. J Fish Biol. 1990;37:241-2.

43. Tsigenopoulos CS, Berrebi P. Molecular phylogeny of North Mediterranean freshwater fauna (genus Barbus: Cyprinidae) inferred from cytochrome $b$ sequences: biogeographic and systematic implications. Mol Phylogenet Evol. 2000;14:165-79.

44. Mrakovčić M, Brigić A, Buj I, Ćaleta M, Mustafić P, Zanella D. Red book of freshwater fish of Croatia. Državni Zavod za Zaštitu Prirode: Croatia; 2006.

45. Tsigenopoulos CS, Durand JD, Unlu E, Berrebi P. Rapid radiation of the Mediterranean Luciobarbus species (Cyprinidae) after the Messinian salinity crisis of the Mediterranean Sea, inferred from mitochondrial phylogenetic analysis. Biol J Linn Soc. 2003;80:207-22.

46. Yang L, Sado T, Vincent Hirt M, Pasco-Viel E, Arunachalam M, Li J, et al. Phylogeny and polyploidy: resolving classification of cyprinine fishes (Teleostei: Cypriniformes). Mol Phylogenet Evol. 2015;85:97-116.

47. Wang J, Wu X, Chen Z, Yue Z, Ma W, Chen S, et al. Molecular phylogeny of European and African Barbus and their west Asian relatives in the Cyprininae (Teleostei: Cyprinoformes) and orogenesis of the QuinghaiTibetian plateau. Chinese Sci Bull. 2013;58:3738-46.

48. Dupont F, Lambert A. Study of communities of Monogenea Dactylogyridae parasites of the Cyprinidae in Lake Mikri Prespa (northern Greece). Description of 3 new species from an endemic Barbus: Barbus cyclolepis prespensis Karaman, 1924. Ann Parasit Hum Comp. 1986;61(6):597-616.

49. Dupont F. Biogeographie historique des Dactylogyrus, monogènes parasites de poisons Cyprinidae dans la peninsula Balkanique. Biol Gallo-hellenica. 1989;13:145-52.

50. Stojanovski S, Kulišić Z, Ra B, Hristovski N, Cakić P, Hristovski M. Fauna of monogenean trematodes - parasites of some cyprinid fishes from Lake Prespa (Macedonia). Acta Vet-Beograd. 2004;54:73-82.

51. Stojanovski S, Hristovski N, Cakic P, Hristovski M. Fauna of monogenean trematodes - parasites of some cyprinid fishes from Lake Ohrid (Macedonia). Nat Montenegr. 2005:4:61-70.

52. Stojanovski S, Hristovski N, Cakic P, Cvetkovic A, Atanassov G, Smiljkov S. Fauna of monogenean trematodes - parasites of cyprinid fish from Lake Dojran (Macedonia). Nat Montenegr. 2008;7:389-98.

53. Stojanovski S, Hristovski N, Velkova-Jordanoska L, Blazekevic-Dimovska D, Atanasov G. Parasite fauna of chub (Squalius squalus Bonaparte, 1837) from Lake Ohrid (Fyrmacedonia). Acta Zool Bulgar. 2012;4:119-22.

54. Stojanovski S, Velkova-Jordanoska L, Blazekevic-Dimovska D, Smiljkov S, Rusinek O. Parasite fauna of Chondrostoma nasus (Linnaeus, 1758) (Teleostei: Cyprinidae) from Lake Ohrid (Macedonia). Nat Montenegr. 2013;12:753-60.

55. Ergens R, Lom J. Causative agents of fish diseases. Prague: Academia; 1970.

56. Malmberg G. Om forekomsten av Gyrodactylus pa svenska fiskar. Skrif Utgivna Sodra Sver Fisker Arsskift. 1956;1957:19-76.

57. Gussev AV. Metazoan parasites. Part I. Key to parasites of freshwater fish of USSR, vol. 2. Leningrad: Nauka; 1985. (In Russian).

58. Bush AO, Lafferty KD, Lotz JM, Shostak AW. Parasitology meets ecology on its own terms: Margolis et al. revisited. J Parasitol. 1997;83:575-83.

59. Mizelle JD. New species of trematodes from Illinois fishes. Am Midl Nat. 1936;17:785-806. 
60. Ergens $R$. The suitability of ammonium picrate-glycerin in preparing slides of lower Monogenoidea. Folia Parasit. 1969;16:320.

61. Šimková A, Plaisance L, Matějusová I, Morand S, Verneau O. Phylogenetic relationships of the Dactylogyridae Bychowski, 1933 (Monogenea: Dactylogyridea): the need for the systematic revision of the Ancyrocephalinae Bychowsky, 1937. Syst Parasitol. 2003;54:1-11.

62. Hassouna N, Michot B, Bachellerie JP. The complete nucleotide sequence of mouse $28 \mathrm{~S}$ rRNA gene. Implications for the process of size increase of the large subunit rRNA in higher eukaryotes. Nucleic Acids Res. 1984;12:3563-83.

63. Pleijel F, Jondelius U, Norlinder E, Nygren A, Oxelman B, Schander C, et al. Phylogenies without roots? A plea for the use of vouchers in molecular phylogenetic studies. Mol Phylogenet Evol. 2008;48:369-71.

64. Katoh K, Misawa K, Kuma K, Miyata TMAFFT. A novel method for rapid multiple sequence alignment based on Fourier transform. Nucl Acids Res. 2002;30:3059-66.

65. Swofford DL. PAUP* phylogenetic analysis using parsimony and other methods. Version 4.0b10. Version 4. Sunderland: Sinauer Associates; 2002.

66. Tamura K, Stecher G, Peterson D, Filipski A, Kumar S. MEGA6: Molecular Evolutionary Genetics Analysis version 6.0. Mol Biol Evol. 2013;30:2725-9.

67. Talavera G, Castresana J. Improvement of phylogenies after removing divergent and ambigously aligned blocks from protein sequence alignments. Syst Biol. 2007;56:564-77.

68. Guindon S, Gascuel OA. Simple, fast and accurate algorithm to estimate large phylogenies by maximum likelihood. Syst Biol. 2003;27:1759-67.

69. Darriba D, Taboala GL, Doallo R, Posada D. JModelTest2: more models, new heuristics and parallel computing. Nat Methods. 2012;9:772.

70. Ronquist F, Teslenko M, van der Mark P, Ayres DL, Darling A, Höhna S, et al. MrBayes 3.2: efficient Bayesian phylogenetic inference and model choice across large model space. Syst Biol. 2012;61:539-42.

71. Guindon S, Dufayard JF, Lefort V, Anisimova M, Hordijk W, Gascuel O. New algorithms and methods to estimate maximum-likelihood phylogenies: assessing the performance of PhyML 3.0. Syst Biol. 2010;59:307-21.

72. de Graaf M, Megens H-M, Samallo J, Sibbing FA. Evolutionary origin of Lake Tana's (Ethiopia) small Barbus species: indicators of rapid ecological divergence and speciation. Anim Biol. 2007;57:39-48.

73. International Commission on Zoological Nomenclature. Amendment of articles 8, 9, 10, 21 and 78 of the international code of zoological nomenclature to expand and refine methods of publication. Bull Zool Nomencl. 2012;69:161-9.

74. Kuraschvili BE, Mikailov TK, Gogebashvili IV. Parasitofauna of fishes in the basin of the River Kura within USSR. Tbilisi: Metsniereba; 1980. (In Russian).

75. Molnár K, Jalali B. Further monogeneans from Iranian freshwater fishes. Acta Vet Hung. 1992;40:55-61.

76. Izjumova NA. Parasitic fauna of reservoir fishes in the USSR and its evolution. Leningrad: Nauka; 1977. (In Russian).

77. Mhaisen FM, Al-Rubaie, A-RL, Al-Sa'adi BA-H. Monogenean parasites of fishes from the Euphrates River at Al-Musaib City, Mid Iraq. Am J Biol Life Sci. 2015:3:50-7.

78. Pazooki J, Masoumian M. Synopsis of the parasites in Iranian freshwater fishes. Iran J Fish Sci. 2012;11:570-89.

79. Pugachev ON, Gerasev PI, Gussev AV, Ergens R, Khotenowsky I. Guide to Monogenoidea of freshwater fish of Palearctic and Amur regions. Milan: Ledizione-Ledi Publishing; 2009.

80. el Gharbi S, Birgi E, Lambert A. Monogenean Dactylogyridae parasites of Cyprinidae of the genus Barbus in North Africa. Syst Parasitol. 1994;27:45-70.

81. Bychowsky BE. Beitrag zur Kenntnis neuer monogenetischer Fischtrematoden aus dem Kaspisee nebst einigen Bemerkungen über die Systematik der Monopishodiscinea Fuhrmann, 1928. Zool Anz. 1933;105:17-38.

82. Šimková A, Pečínková $M$, Řehulková E, Vyskočilová $M$, Ondráčková M. Dactylogyrus species parasitizing European Barbus species: morphometric and molecular variability. Parasitology. 2007;134:1751-65.

83. Galli P, Stefani F, Zaccara S, Crosa G. Occurrence of Monogenea in Italian freshwater fish (Po River basin). Parassitologia. 2002:44:189-97.

84. Jalali B, Barzegar M. Dactylogyrids (Dactylogyridae: Monogenea) on common carp (Cyprinus carpio L.) in freshwaters of Iran and description of pathogenicity of D. sahuensis. J Agric Sci Technol. 2005;7:9-16.

85. Šimková A, Dávidová M, Papoušek I, Vetešník L. Does interspecies hybridization affect the host specificity of parasites in cyprinid fish? Parasit Vectors. 2013;6:95
86. Ling F, Tu X, Huang A, Wang G. Morphometric and molecular characterization of Dactylogyrus vastator and D. intermedius in goldfish (Carassius auratus). Parasitol Res. 2016;115:1755-65.

87. Moravec F. Checklist of metazoan parasites of fishes of the Czech Republic and Slovak Republic, 1873-2000. Prague: Academia; 2001.

88. Shamsi S, Jalali B, Aghazadeh Meshgi M. Infection with Dactylogyrus spp. among introduced cyprinid fishes and their geographical distribution in Iran. Iran J Vet Res. 2009;10:70-4.

89. Uspenskaya AV. Effect of D. vastator Nybelin, 1924 to the organism of common carp. Zool Zh. 1961;40:7-12. (In Russian).

90. Paperna I. Some observations on the biology and ecology of Dactylogyrus vastator in Israel. Bamidgeh. 1963;15:31-50.

91. Vinobaba P. Some aspects of the biology of Dactylogyrus vastator Nybelin, 1924 (Monogenea) a gill parasite of Cyprinus carpio L. PhD Thesis. University of Stirling, UK; 1994.

92. Paperna I. Competitive exclusion of Dactylogyrus extensus by Dactylogyrus vastator (Trematoda, Monogenea) on the gills of reared carp. J Parasitol. 1964;50:94-8.

93. Molnar K. Fifty years of observation about the changes of Dactylogyrus infection of European common carp (Cyprinus carpio L.) in Hungary. Magy Alatorvosok. 2012;134:111-8.

94. Kohlmann K, Gross R, Murakaeva A, Kersten P. Genetic variability and structure of common carp (Cyprinus carpio) populations throughout the distribution range inferred from allozyme, microsatellite and mitochondrial DNA markers. Aquat Living Resour. 2003;16:421-31.

95. Baruš V, Oliva O. Petromyzontes and Osteichthyes. Prague: Academia; 1995. (In Czech).

96. Pouyaud L, Desmerais E, Deveney M, Pariselle A. Phylogenetic relationships among monogenean gill parasites (Dactylogyridea, Ancyrocephalidae) infesting tilapiine hosts (Cichlidae): systematic and evolutionary implications. Mol Phylogenet Evol. 2006;38:241-9.

97. Vignon M, Pariselle A, Vanhove MPM. Modularity in attachment organs of African Cichlidogyrus (Platyhelminthes: Monogenea: Ancyrocephalidae) reflects phylogeny rather than host specificity or geographic distribution. Biol J Linn Soc. 2011;102:694-706.

98. Mendlová M, Desdevides Y, Civáňová K, Pariselle A, Šimková AA. Monogeneans of west African cichlid fish: evolution and cophylogenetic interactions. PLoS One. 2012;7(5):e37268.

99. Mandeng FDM, Bilong Bilong CF, Pariselle A, Vanhove MPM, Bitja Nyom AR, Agnése J-FA. Phylogeny of Cichlidogyrus spp. (Monogenea, Dactylogyridea) clarifies a host-switch between fish families and reveals an adaptive component to attachment organ morphology of this parasite genus. Parasit Vectors. 2015;8:582.

100. Rohde K. Simple ecological systems, simple solutions to complex problems? Evol Theory. 1989;8:305-50.

101. el Gharbi S, Birgi E, Lambert A. Dactylogyrids (Platyhelminthes: Monogenea) of Barbus spp. (Teleostei: Cyprinidae) from the Iberian peninsula. Res Rev Parasitol. 1992;52:103-16.

\section{Submit your next manuscript to BioMed Central and we will help you at every step:}

- We accept pre-submission inquiries

- Our selector tool helps you to find the most relevant journal

- We provide round the clock customer support

- Convenient online submission

- Thorough peer review

- Inclusion in PubMed and all major indexing services

- Maximum visibility for your research

Submit your manuscript at www.biomedcentral.com/submit 